\title{
Lokalna ekonomia a wielka inwestycja przemysłowa. Przypadek Elektrowni Opole i gminy Dobrzeń Wielki ${ }^{1}$
}

\section{Abstract \\ Local Economy versus Major Industrial Investment. The Case of the Opole Power Station and the Dobrzeń Wielki Commune}

The article, based on the so called basic research, concerns the relations between the expansion of the Opole power station and particular actions taken by the residents of the Dobrzen Wielki commune. The text discusses local, bottom-up strategies designed with the use of the potential economic situation resulting from a major industrial investment located in the region. They take the form of various cultural activities, among which bottom-up economic strategies are crucial. The impulses for these activities are supplied by specifically targeted social changes taking place under the influence of supra-local political and economic transformations.

Keywords: local economics, large industrial investment, local community

$\mathrm{W}$ artykule przedstawiono częściowe efekty badań prowadzonych w ramach szerszego projektu badawczego, którego celem było rozpoznanie i analiza interakcji zachodzących pomiędzy zjawiskami towarzyszącymi rozbudowie Elektrowni Opole a społecznością lokalną zamieszkującą obszar bezpośredniego oddziały-

1 Artykuł powstał w ramach grantu badawczego pod tytułem Konflikt, napięcie, współpraca. Studium interakcji pomiędzy Elektrowniq̨ Opole a społecznością gminy Dobrzeń Wielki finansowanego przez Narodowe Centrum Nauki (nr DEC-2013/11/B/HS3/03895). 
wania tej inwestycji. Prezentowany tekst dotyczy więc części szeroko zakrojonych badań diagnozujących wielowymiarowe aspekty funkcjonowania dużej inwestycji przemysłowej w lokalnym świecie.

Warto odnotować, że wśród dotychczasowych opracowań powstałych na podstawie badań o zbliżonej tematyce dosyć często ujawniała się wyraźna opozycja pomiędzy tym, co lokalne, a tym, co globalne. Dostrzegano negatywny wpływ procesów modernizacyjnych na społeczności lokalne, a analizy prowadzono często $\mathrm{z}$ perspektywy konfliktu społecznego ${ }^{2}$. W opisywanym przypadku nie odnotowano tego typu zależności, a wręcz przeciwnie - zaobserwowano, że relacje na osi inwestor-mieszkańcy nie tylko nie powodują napięć społecznych, ale także nastawione są na współpracę, co potwierdzają liczne na ten temat opinie mieszkańców ${ }^{3}$. Należy jednak dodać, że perspektywa konfliktowa pojawiła się w ostatniej fazie badań. Ujawniający się konflikt nie dotyczył bezpośrednio relacji pomiędzy rozbudową elektrowni a społecznością lokalną, ale był skutkiem decyzji politycznych i administracyjnych dotyczących podziału gminy i włączenia jej części do miasta Opole. Fakt ten nie wpłynął dotychczas na analizowaną $\mathrm{w}$ artykule tematykę, a jego konsekwencje mogą być obserwowane dopiero w przyszłości.

Celem tekstu jest przedstawienie i analiza lokalnych oddolnych strategii, budowanych na podstawie potencjalnej koniunktury gospodarczej wynikającej z ulokowania na terenie gminy Dobrzeń Wielki dużej inwestycji przemysłowej, jaką jest rozbudowa Elektrowni Opole. Będące w tym przypadku przedmiotem badań spontaniczne działania społeczne i kulturowe postrzegane są często przez badaczy jako inicjatywy podejmowane poza sformalizowanymi instytucjami, służące konstruowaniu świata społecznego oraz tożsamości indywidualnej czy lokalnej. Istnieje zgoda na to, że przedsięwzięcia te mogą wiązać się z rozmaitymi zjawiskami natury politycznej, społecznej czy ekonomicznej, zachodzącymi zarówno w skali regionalnej, jak i globalnej. To właśnie w reakcji na tego typu zjawiska bywają podejmowane działania, które wpisują się w szerszą kategorię określaną mianem działań oddolnych ${ }^{4}$. Przybierają one postać różnorodnych form aktywności kulturowych, wśród których największe znaczenie mają oddolne strategie

2 Dobrym tego przykładem jest niezwykle aktualna praca o konfliktach społecznych wywołanych $\mathrm{w}$ województwie lubuskim planowanymi inwestycjami przemysłowymi: D. Szaban, Gra o wegiel. Socjologiczne uwarunkowania konfliktu wokót planów powstania kompleksu energetyczno-wydobywczego w województwie lubuskim, Warszawa 2017.

3 W kategoriach społecznego konfliktu można jednak rozpatrywać zjawiska zachodzące na przełomie lat 80. i 90. podczas budowy elektrowni. Jej rozbudowa przebiega w zupełnie innych warunkach, niewymagających nowych terenów inwestycyjnych i bezpośredniego ingerowania w życie mieszkańców.

4 Szerzej o oddolnych procesach kulturowych zachodzących w mikroskali piszą autorzy pracy: Oddolne tworzenie kultury. Perspektywa antropologiczna (Cichocki, Dudek, Rakowski 2015). 
ekonomiczne, a impulsów dostarczają im w określony sposób ukierunkowane zmiany społeczne $e^{5}$.

Uchwycenie specyfiki oddolnych przedsięwzięć o charakterze ekonomicznym możliwe było dzięki intensywnym etnograficznym badaniom terenowym, które prowadzono w latach 2014-2016, czyli w okresie największego natężenia prac związanych z rozbudową Elektrowni Opole ${ }^{6}$. Materiał terenowy został więc pozyskany w toku rozmów z mieszkańcami gminy, zwłaszcza tymi, którzy prowadzą rozmaite działalności gospodarcze. Rozmowy te, często w formie niestandaryzowanych i nieustrukturyzowanych wywiadów, dotyczyły prowadzenia działalności gospodarczej, jej rodzajów, lokalnej specyfiki i uwarunkowań, a zwłaszcza relacji pomiędzy prowadzeniem „biznesu” a funkcjonowaniem i rozbudową elektrowni. Należy dodać, że analizie poddane zostały również upublicznione przez urząd gminy dokumenty, które okazały się istotnym elementem wiedzy na temat badanej problematyki ${ }^{7}$.

Wraz z postępującym przebiegiem przemian modernizacyjnych zachodzących w skali krajowej oraz wpływami szerszych procesów o charakterze globalizacyjnym następowały zmiany w lokalnych aktywnościach ekonomicznych. Zjawiska takie zachodziły również w gminie Dobrzeń Wielki, która na przełomie lat 80 . i 90. doświadczyła problemów związanych z upadaniem zakładów pracy i pojawieniem się coraz większego bezrobocia (Kałuża 2000: 59). Reakcją na to był rosnący udział osób zakładających najczęściej jednoosobowe i rodzinne działalności gospodarcze. Drobne handlowe i usługowe firmy, powstające zwłaszcza po roku 1989, rozwijały się wolno i tylko niektóre $\mathrm{z}$ nich były w stanie utrzymać się na rynku czy rozszerzyć swoją działalność. Sytuacja ta zaczęła powoli ulegać zmianie od momentu, gdy na terenie gminy przystąpiono do uruchomiania elektrowni (1993-1997), która wkrótce stała się znaczącym źródłem dochodów i jednym z powodów zachodzących w szybkim tempie procesów modernizacyjnych. Dzięki nim gmina systematycznie traciła dotychczasowy rolniczo-przemysłowy charakter, przekształcając się w obszar, na którym dominują przemysł oraz gospodarka handlowo-usługowa ${ }^{8}$.

5 W Polsce zaczęły one zachodzić po 1989 roku wraz z przekształceniami politycznymi i ekonomicznymi. Rezultatem tych przemian było podejmowanie rozmaitych lokalnych działań adaptacyjnych, które stały się przedmiotem badań antropologicznych, zaś ich rezultaty zostały już opublikowane: Buchowski 1995; Rakowski 2009 oraz nowsze publikacje: Buchowski 2018; Kuligowski, Stanisz 2017.

6 Zawarte w tekście stwierdzenia, które nie zostały poparte literaturą, pochodzą z badań własnych autora i oparte są na rozmowach i wywiadach etnograficznych znajdujących się w archiwum projektu badawczego.

7 Dokumenty te są dostępne w archiwum oraz częściowo na stronie internetowej Urzędu Gminy Dobrzeń Wielki i dotyczą głównie publicznej statystyki lokalnej przedsiębiorczości i struktury finansowych wpływów i wydatków gminy.

8 Już w 2000 roku na terenie gminy funkcjonowało kilkanaście dużych przedsiębiorstw, co odnotowane zostało w badaniach socjologów: Lesiuk 2000: 8. 
Pojawienie się elektrowni pociągnęło za sobą szereg zmian w krajobrazie środowiskowym i rozpoczęło proces powstawania nowych form przedsiębiorczości, zaczynając od firm ściśle związanych $\mathrm{z}$ tą inwestycją, po działalności gospodarcze wychodzące naprzeciw potrzebom nowych mieszkańców gminy, przybyłych $\mathrm{z}$ różnych stron kraju do pracy w elektrowni. $\mathrm{Z}$ upływem czasu dostrzegalna zaczęła być sieć powiązań ekonomicznych, w środku której znajdowała się Elektrownia Opole. Z jej majątku w wyniku procesów prywatyzacyjnych, wyodrębniono tak zwane spółki córki, które z czasem się usamodzielniły. Równolegle do nich powstały większe zakłady przemysłowe nastawione na wykorzystanie ubocznych produktów wytworzonych w wyniku procesu spalania węgla oraz inne zakłady, niemające związku z funkcjonowaniem elektrowni. Przedsiębiorstwa te są obecnie podstawowym miejscem zatrudnienia dla mieszkańców gminy i okolic. Potencjał związany z funkcjonowaniem stosunkowo wielu dużych podmiotów gospodarczych stał się jedną z podstaw rozwoju małej przedsiębiorczości. Z analizy dokumentów urzędu gminy wynika, że liczba niewielkich zakładów o charakterze handlowo-usługowym i produkcyjnym była na terenie gminy znacznie większa niż w gminach ościennych i stanowiła o jej potencjale ekonomicznym. Sieć ta powstawała przez wiele lat, a jej dalszego rozwoju w wielu przypadkach przedsiębiorcy upatrywali w rozbudowie elektrowni zaplanowanej na lata 2014-2019.

Wraz z nową inwestycją rozbudzono więc wiele oczekiwań związanych z ekonomicznym rozwojem gminy i firm działających na jej terenie. Rzeczywistość okazała się jednak inna, bowiem rozbudowa elektrowni nie miała decydującego wpływu na funkcjonowanie lokalnej ekonomii. Związek wielkiej inwestycji przemysłowej ze społecznością lokalną był jedynie pośredni, a miejscowi przedsiębiorcy zostali zmuszeni do odnalezienia takich wspólnych obszarów inwestycji, które miały im pozwolić na wykorzystanie faktu rozbudowy w prowadzeniu własnych działalności gospodarczych. Wielu przedsiębiorców poradziło sobie w nowej sytuacji i rozpoznało, że ewentualne przychody finansowe wynikające $\mathrm{z}$ faktu rozbudowy elektrowni uzyskać można przede wszystkim z dwóch aspektów działalności gospodarczej: świadczenia usług i prowadzenia handlu.

W działalności usługowej chodziło przede wszystkim o wynajem mieszkań, miejsc noclegowych dla kolejnych firm, które zależnie od czasochłonności zlecanych im prac rezerwowały noclegi dla swoich pracowników. Ich pobyty były często wielotygodniowe, wielomiesięczne, a nawet dłuższe, co gwarantowało stabilne i przewidywalne zyski. Zdarzało się, że firmy te nie zwracały uwagi na wysoki standard oferowanych usług, chociaż kadra kierownicza oczekiwała wyższej jakości miejsc noclegowych i zapewnienia na przykład dostępu do szybkiego łącza internetowego. Cena najmu była kwestią bezpośrednich rokowań, a osiągane zyski oceniano jako wysokie. Usługodawcy musieli sprostać konkurencji, co czasami prowadziło do nieporozumień. W związku z tym obserwowano zjawisko wzajemnego posądzania się oferentów noclegów o ukrywanie faktycznej liczby osób nocujących, a co za tym idzie - rzeczywistych przychodów. 
W kwestii wynajmu miejsc noclegowych mieszkańcy gminy przyjęli bardzo różne strategie. Powstało lub zostało wyremontowanych niewiele miejsc o standardzie hotelowym. Dominowało natomiast wykorzystywanie dotychczasowej zabudowy i powierzchni mieszkaniowej. Na bieżąco dokonywano jedynie drobnych remontów, przeróbek, wyposażając pomieszczenia najmniejszym kosztem. Zdarzali się nawet właściciele sklepów spożywczych czy barów, których interesy ze względu na rozbudowę sieciowych marketów mocno podupadły. Stąd też w poszukiwaniu nowych źródeł zyskownego dochodu osoby te przerabiały je na miejsca noclegowe. Mieszkańcy zdawali sobie sprawę, że popyt na lokale do wynajęcia jest chwilowy i będzie wygasał wraz z postępami w rozbudowie oraz zakończy się ostatecznie po oddaniu do użytku nowych bloków energetycznych. Z tego powodu nadmierne inwestowanie $\mathrm{w}$ budowę nowych obiektów, remontowanie i modernizacja mieszkań nie były opłacalne ani konieczne, bowiem każda oferta spotykała się z ogromnym zainteresowaniem firm, które wolały zapłacić większe kwoty, niż borykać się z kosztownym transportem pracowników do elektrowni z odległych miejsc. $Z$ remontami pomieszczeń przeznaczonych dla pracowników i budową hotelików wiązał się zwiększony popyt na prace budowlane. Z tego powodu firmy handlujące materiałami budowlanymi, wyposażeniem wnętrz, zajmujące się stolarką okienną, instalacją elektryczną, oferujące usługi telewizyjne, serwis rolet, okien, bram elektrycznych i tym podobne odnotowywały znacznie więcej zamówień. Z kolei właściciele lokalnych firm zainteresowani wynajmem mieszkań, pokoi hotelowych, na przykład dla swoich gości i kontrahentów, zauważyli, że rynek mieszkaniowy w gminie, ale i w Opolu „mocno się skurczył”, a ceny znacznie wzrosły. Tym samym wzrosły koszty działalności ich firm.

Przyglądając się strategiom podejmowanym w ramach rozwoju bazy noclegowej, można zaobserwować wyraźny podział na dwa segmenty działań. Jeden $\mathrm{z}$ nich charakteryzowała tymczasowość, drugi natomiast oparty został na długofalowym, przemyślanym planie biznesowym. Jako przykład może posłużyć działalność dwóch hoteli, z których każdy przyjął odmienny model funkcjonowania i rozwoju. Właściciel hotelu „Pod kominem” położonego w bezpośrednim sąsiedztwie elektrowni wykorzystał chwilową koniunkturę i znaczną część dochodu z wynajmu pomieszczeń przeznaczył na modernizację i podniesienie standardu oferowanych usług. Początkowo wieloosobowe pokoje hotelowe przeznaczone były przede wszystkim dla robotników pracujących na placu budowy nowych bloków elektrowni i cechowały się niskim standardem. W późniejszym czasie pozwolić to miało na taką poprawę jakości świadczonych usług, by po zakończeniu rozbudowy elektrowni docelowymi klientami hotelu mogła być kadra kierownicza, goście czy różnego rodzaju specjaliści wykonujący prace na rzecz elektrowni.

Inaczej przedstawiała się sytuacja w hotelu, który mieści się w Dobrzeniu Małym. Został on wybudowany od podstaw tuż przed rozpoczęciem rozbudowy, a jego właściciel zdecydował się na wykorzystanie dotacji z Unii Europejskiej. W tym wypadku wykorzystanie koniunktury polegało na uzyskaniu środków 
finansowych, które pozwalałyby spłacić zaciągnięte kredyty i kontynuować działalność hotelu po rozbudowie. Podkreślić trzeba, że od samego początku oferowany standard usług był na wysokim poziomie, a w planach właściciel hotelu miał jego rozbudowę o część rekreacyjną. Tu z kolei klientami docelowymi mają być turyści, a zwłaszcza członkowie rodzin, które wyemigrowały do Niemiec i obecnie chętnie odwiedzają swoje rodzinne strony. Ważną częścią działalności hotelu była i jest organizacja różnego rodzaju imprez okolicznościowych.

Drugiego aspektu zyskownej działalności upatrywano w handlu. Zwiększonych wpływów spodziewano się zwłaszcza w branży spożywczej. Liczono na to, że zatrudnieni przy rozbudowie pracownicy będą zaopatrywać się w sklepach funkcjonujących na terenie gminy. Rzeczywiście tak się stało, ale handel został niemal zmonopolizowany przez sklepy sieciowe i markety, takie jak Dino, Biedronka czy Tesco, stąd małe, rodzinne sklepy jedynie w niewielkim stopniu odczuły poprawę koniunktury. Od tej reguły znaleźć można jednak wyjątki wskazujące na umiejętność przystosowania się do zmieniających się warunków. Na przykład właścicielka jednego ze sklepów mięsnych jednoznacznie stwierdziła, że sprzedaje indywidualnym klientom znacznie więcej towaru i dowozi go również na zlecenie niektórym firmom. Klientami byli również obcokrajowcy zatrudnieni przy rozbudowie. Z perspektywy właścicielki sklepu ważna była przede wszystkim jakość oferowanych towarów, bowiem zainteresowaniem cieszyły się produkty regionalne, naturalne wyroby, zwłaszcza niezawierające konserwantów.

Inne rozwiązanie wobec wzrostu konkurencji przyjęła właścicielka jednego z rodzinnych sklepów spożywczych, która zmieniła branżę na handel obuwiem, co okazało się niezwykle trafionym przedsięwzięciem. Dodać należy, że jest to również sklep oferujący obuwie w Internecie, co świadczyć może o innowacyjności i umiejętności radzenia sobie w obliczu zmieniających się warunków prowadzenia działalności gospodarczej. Zatem i w tym wypadku liczyły się przede wszystkim mniej lub bardziej trafione strategie oparte na uzasadnionych ekonomicznie decyzjach. Bardzo istotną kwestią wpływającą na obniżenie kosztów prowadzenia działalności gospodarczej jest jej umiejscowienie na własnej posesji, co w przypadku badanej gminy było bardzo często spotykane. Zazwyczaj decydujące znaczenie w uruchomieniu działalności ma lokalizacja, która jest tym korzystniejsza, im bliższa głównym traktom komunikacyjnym.

Beneficjentami wyjątkowo zadowolonymi z rozbudowy elektrowni okazali się właściciele stacji benzynowych, którzy odnotowali znaczne zwiększenie popytu, a zatem wzrost obrotów i zysków. Musieli oni szybko przystosować się do nowej sytuacji, zmieniając także asortyment towarów oferowanych we własnych całodobowych sklepach. Dotyczyło to nawet rzeczy z pozoru bardzo drobnych, na przykład konieczności wprowadzenia do obrotu dużej kawy zamiast małej, bowiem nowi klienci takiej oczekiwali. Dodać można, że ze stacji paliw korzystają obecnie także małe miejscowe firmy transportowe, które pracują głównie na potrzeby elektrowni. 
Napływ pracowników rozbudowujących elektrownię spowodował również zwiększenie popytu na usługi gastronomiczne i cateringowe, jednak z prowadzonych $\mathrm{w}$ trakcie badań obserwacji wynikało, że właściciele miejscowych restauracji czy punktów tak zwanej małej gastronomii nie zwiększyli znacząco swoich przychodów. Trzeba pamiętać, że robotnicy korzystali głównie ze stołówek umiejscowionych przy elektrowni oraz przygotowywali posiłki we własnym zakresie, co wynikało z oszczędności oraz dostępu do kuchni w miejscach zakwaterowania. Ważne jest też to, że duże restauracje nie przystosowały swojej oferty do nowych warunków, która mogłaby polegać na zaproponowaniu tanich posiłków dla pracowników firm czy konsorcjum będącego głównym wykonawcą projektu rozbudowy. $Z$ tego powodu najczęstszymi klientami ciągle są mieszkańcy gminy, przy czym, jak twierdzą właściciele, systematycznie zanika zwyczaj rodzinnego stołowania się w restauracjach w weekendy czy dni wolne od pracy. Podstawowy zysk osiągany jest więc $z$ organizacji przyjęć weselnych i innych imprez rodzinnych i okolicznościowych.

Wśród innych beneficjentów rozbudowy elektrowni wymienić można na przykład firmy zajmujące się usługami reklamowymi, produkcją banerów, szyldów i tym podobnych. Dla nich elektrownia zawsze była dobrym klientem, a pojawienie się przy jej rozbudowie nowych przedsiębiorstw stało się kolejną okazją na zwiększenie zysków. Pomimo że niektóre firmy przywoziły z sobą materiały promocyjne, to jednak wielu przedsiębiorców ich wykonanie zlecało miejscowym, nawet całkiem małym podmiotom gospodarczym.

Kolejnym przykładem mogą być warsztaty samochodowe, choć w tym wypadku sytuacja była niejednoznaczna. Zwiększone przychody odnotowywały zwłaszcza te warsztaty, które usytuowano w widocznym, dobrze oznakowanym miejscu. Jeden $\mathrm{z}$ właścicieli stwierdził na przykład, że wzrosła liczba klientów indywidualnych pochodzących z różnych części Polski i z zagranicy. Udało mu się nawiązać współpracę z wieloma firmami wykonującymi prace dla elektrowni i prowadzić dla nich naprawy aut oraz świadczyć inne usługi. Nowi klienci byli często zmuszeni do korzystania z jego usług ze względu na dużą odległość od miejsca zamieszkania czy zarejestrowania firmy. Jako jeden z niewielu respondentów dostrzegł ich rzetelność. Tłumaczył to specyfiką działania konsorcjum realizującego rozbudowę elektrowni, które monitoruje firmy wykonawcze, i jeśli zdarzy się, że nie spełniają one określonych wymogów, umowy z nimi mogą być rozwiązane. Tacy podwykonawcy nie byli więc przypadkowi, a selekcję dokonywaną przez konsorcjum uznano za gwarancję tego, że również miejscowym firmom zapłacą one uczciwie i terminowo. Na podobnej zasadzie znacząco zwiększyła zyski Okręgowa Stacja Kontroli Pojazdów w Czarnowąsach obsługująca na przykład dużą część samochodów ciężarowych wykorzystywanych przy rozbudowie, a także zarejestrowanych $w$ firmach współpracujących z elektrownią. Podobnie było $\mathrm{w}$ innych, ale nie we wszystkich, warsztatach samochodowych i naprawczych, zwłaszcza tych, które położone są na uboczu. Przykładem zawiedzionych nadziei 
na zwiększony dochód mogły być wypowiedzi świadczące o tym, że nie przybyło wielu nowych klientów. Pojawiali się oni sporadycznie i oczekiwali tanich, szybkich, tymczasowych napraw jedynie w przypadku nagłych awarii. Gruntownych napraw, modernizacji dokonywali w miejscach swojego zamieszkania, zwłaszcza wtedy, gdy poruszali się na przykład samochodami służbowymi.

Dobra koniunktura sprzyjała miejscowym firmom zajmującym się szkoleniami, doradztwem, kontrolą i nadzorem BHP, projektami i nadzorem budowlanym, współpracującym z podwykonawcami i wykonawcami rozbudowy elektrowni. $\mathrm{W}$ tym przypadku koniunktura sprzyjała liczbie zleceń i wpływom finansowym. Odkąd przez gminę zaczęło się przewijać znacznie więcej ludzi, zyski odnotował nawet zakład fotograficzny, którego klientami stali się przyjezdni pracownicy z Polski i zagranicy, zlecający wykonanie fotografii niezbędnych do wyrobienia koniecznych dokumentów. Wzrost sprzedaży dotyczył również sprzętu AGD, a nowych klientów pozyskał także sklep z pasmanterią czy firma zajmująca się projektowaniem ogrodów.

Dodać należy, że pozytywnie o rozwoju gminy, wysokim standardzie życia, infrastrukturze wypowiadały się również osoby, które jej nie zamieszkiwały, a prowadziły w niej tylko działalność gospodarczą. Porównanie z sąsiednimi gminami, a nawet miastem Opole, wypadało na jej korzyść. Bogactwa gminy upatrywano głównie w umiejscowieniu na jej terenie elektrowni traktowanej jako gwaranta stabilności finansowej. Gmina w ten sposób stała się atrakcyjnym partnerem dla przedsiębiorców korzystających z różnych udogodnień oraz zleceń, jakie im oferowała. W innych częściach Opolszczyzny sytuacja taka była rzadkością, co nie może dziwić, gdyż gmina Dobrzeń Wielki była najbogatszą gminą wiejską $\mathrm{w}$ regionie.

Ze względu na bezpośredni udział w rozbudowie, a wcześniej budowie elektrowni oraz rolę, jaką odgrywa w lokalnej społeczności, na szczególną uwagę zasługuje firma Kociok. Jej właściciel rozwinął własną działalność jeszcze w trakcie budowy elektrowni. Skłoniły go do tego osobiste obserwacje z placu budowy, na którym przez krótki czas pracował. Według niego dostrzegalny był wówczas przede wszystkim brak organizacji pracy. Obserwacja ta oraz doświadczenia z wizyty w Niemczech, gdzie spotkał się z zupełnie odmiennymi wzorcami, skłoniły go do założenia własnej firmy, która wkrótce otrzymała pierwsze zlecenia od elektrowni w końcowym etapie jej budowy. Od momentu uzyskania informacji o rozbudowie firma rozpoczęła przygotowania do uczestnictwa w przetargach ogłaszanych przez konsorcjum kierujące inwestycją. Polegały one na zakupie nowego sprzętu czy powiększeniu zatrudnienia, tak aby sprostać dużej konkurencji na rynku. Niewątpliwym atutem firmy było i jest umiejscowienie jej na terenie gminy, czyli w bliskim sąsiedztwie placu budowy, co pozwoliło znacznie ograniczyć koszty pracy i zaoferować tańsze usługi. W rezultacie firma wygrała szereg przetargów związanych na przykład z robotami ziemnymi oraz traktowana była przez konsorcjum jako ta, $\mathrm{z}$ której usług korzystać można w nagłych przypadkach, przy 
tak zwanych pracach interwencyjnych. Można dodać, że właściciel, przewidując skomplikowany proces odbioru wykonywanych zleceń, konieczność wystawiania certyfikatów płatności, zadbał o zapewnienie rezerw finansowych pozwalających na płynną działalność. Interesujące wydają się również refleksje właściciela na temat postaw mieszkańców gminy, którzy niemal nie korzystali z faktu umiejscowienia elektrowni w ich sąsiedztwie. Nie starali się czerpać z niej żadnych profitów, ignorując nawet zatrudnienie oferowane przez firmy zaangażowane w proces rozbudowy. Proponowane zarobki uważano za zbyt niskie, a pracę za zbyt ciężką, licząc na intratne etaty na przykład w Niemczech, stąd też firma zmuszona była do zatrudniania specjalistów spoza gminy ${ }^{9}$.

Przedsiębiorstwo Kociok jest przykładem dynamicznie rozwijającej się firmy umiejętnie wykorzystującej możliwość uzyskiwania dochodów z prac wykonywanych przy rozbudowie elektrowni. Między innymi dzięki nim firma stabilnie się rozwinęła, mimo że w ocenie jej właściciela zlecenia dotyczące rozbudowy stanowiły, zwłaszcza pod koniec prac inwestycyjnych, tylko około 30\% jej mocy przerobowych. Wynika z tego, że większa część działalności gospodarczej prowadzona była nie tylko przy rozbudowie i na terenie gminy, ale przede wszystkim na rynku ponadlokalnym. Jest to więc bardzo dobry przykład na to, jak oddolna inicjatywa gospodarcza przeradza się, dzięki współpracy z elektrownią, w przedsiębiorstwo, dla którego miejscowy rynek staje się zbyt mały i nie zapewnia wykorzystania potencjału firmy. Dotyczy to również kilku innych dużych przedsiębiorstw, dla których gmina przestała być ekonomicznym partnerem. Ich właściciele, zatrudniający kilkunastu czy kilkudziesięciu pracowników, mieli pretensje do gminy o to, że wnoszą do jej budżetu duże kwoty z podatków, a nie są traktowani poważnie i są narażeni na liczne ograniczenia. Ich zdaniem niesłusznie zarzucano im nadmierną eksploatację i niszczenie dróg, generowanie uciążliwego hałasu, zadymienia, kurzu oraz degradację środowiska gminy. Niektórzy przedsiębiorcy stwierdzali, że sugerowano im nawet ograniczenie działalności, i zwracali uwagę na to, że władze gminy przychylne miały być jedynie mieszkańcom, którzy doceniają przede wszystkim spokojny, wiejski model życia lub traktują gminę jako sypialnię. Stąd wśród tej grupy przedsiębiorców o wiele częściej pojawiały się opinie, że urząd gminy powoli przestaje być dla nich atrakcyjnym kontrahentem, a preferuje osoby prowadzące drobną, na przykład usługową, działalność, którym gmina stwarzała z kolei znakomite warunki.

9 Problem ten podnoszą również właściciele innych firm, zauważając zjawisko braku rąk do pracy, tak jak kierownik firmy zajmującej się sprzedażą i montażem okien: „Powiem szczerze, że jest taki problem $\mathrm{z}$ fachowcami, że czekamy, żeby tacy przyjechali. Bo w tym akurat regionie są bardzo duże problemy z ludźmi do pracy. Ja wiem, że tam może być kwestia finansów itd., ale nawet takich młodych ludzi do takich prac, powiedzmy, niewymagających jakiejś większej wiedzy i doświadczenia, to i tak jest problem z pracownikami. Tak, że sprowadzani są ludzie z zagranicy, głównie z Ukrainy, to jak będzie więcej ludzi do pracy, to dla nas lepiej” (przedsiębiorca ze wsi Brzezie, obecnie części Opola). 
Niech przykładem będzie wypowiedź osoby porównującej traktowanie jej przez urzędników w Opolu i Dobrzeniu Wielkim. Osoba ta nie tylko nie otrzymała właściwej pomocy od urzędników miejskich, ale także została poinformowana o różnych problemach towarzyszących założeniu własnej działalności gospodarczej w branży, którą zaproponowała:

Dlaczego pani to chce założyć? Pani wie, jakie to szkodliwe dla miasta? A pani wie, że to są uciążliwe usługi? A czy pani wie, że pani będzie musiała mieć zgody sąsiadów? A pani wie, że pani będzie musiała mieć zgody z ochrony środowiska? (urzędnik miejski w Opolu)

Zgoła inaczej w takiej sytuacji zachowali się urzędnicy gminy Dobrzeń Wielki:

A przyszłam do gminy, weszłam i mówię, że miałabym zamiar szukać kawałka ziemi i [...] otworzyć taką i taką placówkę. „A może pani pójść do wójta? Bardzo panią serdecznie zapraszam”. Ja przyszłam, mówię mu, o co chodzi. „Proszę pani, my zrobimy wszystko, żeby to pani ułatwić. Ja pani wyznaczę pracownika, który panią poprowadzi za rękę. My się bardzo cieszymy, że taka placówka powstanie w naszej okolicy, bo jej jeszcze nie ma. My będziemy pani bardzo pomagać". Poszedł ze mną do wydziału budownictwa, przydzielił mi osobę i ta osoba mnie rzeczywiście prowadziła za rękę. Ja po trzech miesiącach mam wszystko. Łącznie ze zgodą budowlaną. Widzi pan różnicę? Bo ja widzę [...] ma pan jakiś problem, przyjdzie pan do odpowiedniego okienka placówki, powie pan, z czym się pan boryka, proszę usiąść, ja pomogę, jestem od tego. Mają czas, mają chęci (mieszkanka Czarnowąsów).

Dobrym przykładem rozbieżności pomiędzy małymi a dużymi przedsiębiorcami była ocena budowy planowanej obwodnicy pięciu gminnych miejscowości położonych przy drodze krajowej nr 454 oraz tego, jak jej funkcjonowanie wpłynie na działalność gospodarczą prowadzoną w tych miejscowościach. W tym wypadku obawy wyrażali przedstawiciele tak zwanego małego biznesu usytuowanego przede wszystkim w bezpośrednim sąsiedztwie drogi krajowej. W ich przekonaniu zmniejszenie natężenia ruchu drogowego spowoduje istotne ograniczenie liczby klientów, redukcję wpływów pochodzących ze sprzedaży czy usług i stanowić może zagrożenie dla działalności firm:

Jak jeszcze wybudują obwodnicę, to Dobrzeń Wielki będzie zwykłą słabo rozwiniętą wsią, typowo na uboczu, zdecydowanie rozbudowa elektrowni przyniesie więcej strat lub nic się nie zmieni. Do nas już mniej klientów zagląda, nasz sklep jest ostatni we wsi (mieszkaniec Dobrzenia Wielkiego).

W odmienny sposób powstanie obwodnicy oceniali więksi przedsiębiorcy, zwłaszcza ci, dla których działalności duże znaczenie mają łatwość i szybkość transportu i komunikacji. W tym przypadku obwodnica miałaby sprzyjać mobilności i obniżać koszty, zatem z tej perspektywy była inwestycją oczekiwaną i pożądaną.

Warto dodać, że gdy mowa o kwestiach związanych z komunikacją i transportem, mieszkańcy gminy zauważali stracone szanse związane z możliwością wykorzystania rzeki Odry. Jest ona przebiegającym przez terytorium gminy Dobrzeń 
Wielki naturalnym szlakiem wodnym, który pozostaje niedoceniony. Mieszkańcy nie rozumieli, dlaczego węgiel dostarczany do elektrowni jest transportowany koleją, a wszelkie dostawy - transportem kołowym. Decydentom zarzucano niepodejmowanie działań prowadzących do przywrócenia transportu wodnego, modernizacji portu, który funkcjonował tu w przeszłości. Niektórzy mieszkańcy wspominali czasy, gdy Odrą barki transportowały węgiel z Górnego Śląska, a płynąc z powrotem w górę rzeki, przewoziły rzeczny muł, którym później wypełniano korytarze w kopalniach. Za zwiastun zmian w tej kwestii uważano niedawno wyremontowaną śluzę umiejscowioną na wysokości wsi Chruścice, gdzie kilkoro mieszkańców gminy znalazło pracę. Przypuszczać można, jak zresztą twierdzą lokalni przedsiębiorcy, że uruchomienie portu rzecznego powiększyłoby potencjał ekonomiczny gminy.

Rozbudowa elektrowni wpłynęła więc na rozwój przedsiębiorczości w gminie Dobrzeń Wielki. Duża inwestycja przemysłowa stała się przyczyną i okazją do restrukturyzacji dotychczasowego potencjału ekonomicznego, co szczególnie obrazowała dynamika powstawania czy przebranżawiania się istniejących już podmiotów gospodarczych. Ich liczbę szacowano na prawie tysiąc, z ogromną przewagą firm prywatnych, wśród których z kolei większość stanowiły małe, często jednoosobowe podmioty gospodarcze. Stwierdzenie, że takie oddolne praktyki ekonomiczne podejmowane w społeczności lokalnej gminy były związane tylko z rozbudową elektrowni, nie jest uzasadnione. Także tylko z pozoru jedyną widoczną konsekwencją nowej inwestycji było powstanie i rozwój bazy noclegowej dla robotników budowlanych, pracowników konsorcjum i Elektrowni Opole, czy zwiększony popyt na usługi i handel. Rozpatrując wzajemne relacje pomiędzy społecznością lokalną gminy Dobrzeń Wielki a Elektrownią Opole, można stwierdzić, że dużo większe znaczenie ma jej wieloletnie funkcjonowanie na terenie gminy niż sama rozbudowa oddziałująca na miejscowe środowisko w ciągu ostatnich kilku lat. To przede wszystkim budowa i dotychczasowe funkcjonowanie elektrowni, a nie jej rozbudowa, odcisnęła piętno na historii gminy oraz jej współczesności. Nagły wzrost liczby mieszkańców, a tym samym zwiększenie popytu na usługi i handel, uwolnił potencjał i kreatywność lokalnych, oddolnych inicjatyw o charakterze ekonomicznym.

Nie bez znaczenia w tym względzie jest otoczenie kulturowe, w którym zachodziły opisywane procesy. Istotna jest dla niego tożsamość i hołdowanie określonym wartościom, takim jak przywiązanie do zamieszkiwanej przestrzeni, wspólnotowość czy etos pracy. Na efektywne realizacje strategii ekonomicznych miał zatem wpływ „przedsiębiorczy habitus”, związany w tym wypadku z zasiedziałą ludnością pochodzenia śląskiego, czy też środowiska mniejszości niemieckiej. Takie spostrzeżenie wymaga bez wątpienia pogłębionych badań porównawczych ${ }^{10}$. Tymczasem wypada stwierdzić, że społeczność ta wniosła na teren gminy wzory,

10 Podobne kwestie zauważone zostały w trakcie badań wpływu autostrady A2 na lokalne krajobrazy kulturowe (Kuligowski, Stanisz 2017: 316). 
które po 1989 roku nie były powszechnie znane w polskim krajobrazie kulturowym. Chodzi tu zwłaszcza o modele funkcjonowania inicjatyw gospodarczych, przemyślane i uzasadnione ekonomicznie przedsięwzięcia poparte odwagą w podejmowaniu decyzji, zaradnością oraz przekonaniem o ich efektywności. Umiejętności te mieszkańcy posiedli, pracując na przykład w Niemczech i innych wysoko rozwiniętych państwach Europy Zachodniej, gdzie mieli styczność z odmiennym systemem organizacji pracy, relacji pomiędzy jej jakością a wynagrodzeniem. Wyposażeni w tę wiedzę mogli bez trudu sprostać wymogom, jakie postawiła przed nimi zmiana systemowa w Polsce. Istotną rolę w tym wypadku odegrał także fakt posiadania przez nich zgromadzonego za granicą kapitału, który w dużej części mógł zostać zainwestowany we własne działalności gospodarcze $\mathrm{w}$ miejscu zamieszkania. Nawet w przypadku niepowodzenia tego rodzaju przedsięwzięć, dysponowali oni możliwością powrotu do dotychczasowego sposobu życia, czyli wyjazdu za granicę w celach zarobkowych. Ponadto, wracając do kraju, przenosili oni w rodzinne strony doświadczenia i standardy życia zaobserwowane za granicą, co przyczyniło się na przykład do modernizacji i rozbudowy własnego otoczenia i środowiska. Podobne wzory i wysokie standardy zachodnioeuropejskie zostały zaaplikowane do modelów sprawowania władzy i zarządzania gminą, która dzięki temu modernizowała się w szybkim tempie. Nie byłoby to jednak możliwe, gdyby nie bardzo dobra kondycja finansowa gminy, na co ogromny wpływ miała obecność na jej terenie elektrowni. Konsekwentna polityka ekonomiczna władz gminy, umiejętne wydatkowanie środków finansowych, perspektywiczne plany działania sprzyjały lokowaniu na terenie gminy nowych firm, a zatem powstawaniu nowych miejsc pracy i wielu inicjatyw oddolnych. Wszystkie tego typu zjawiska tworzyły nierozłączną sieć powiązań ekonomicznych i ugruntowały sposoby przepływu kapitału pomiędzy wielkim przemysłem, zasobami finansowymi gminy i drobnymi przedsiębiorcami. Związane z tym sukcesy gospodarcze gminy przełożyły się bezpośrednio na wysoką jakość codziennego życia jej obywateli oraz przyciągały coraz większą liczbę nowych mieszkańców zainteresowanych nie tylko zamieszkaniem w zadbanej i przyjaznej pod względem świadczeń socjalnych gminie, ale i ulokowaniem w niej własnego biznesu.

Decydujące w dużej mierze o egzystencji społeczności gminy relacje ekonomiczne pomiędzy lokalną przedsiębiorczością a funkcjonowaniem i rozbudową Elektrowni Opole określały więc specyfikę powiązań społeczno-ekonomicznych i podejmowanych $w$ ich ramach oddolnych aktywności ekonomicznych. Specyfika ta wpływała również na plany rozwoju opracowywane zgodnie z długofalowymi strategiami przez gminne władze. Dodać należy, że takie długookresowe planowanie możliwe było dzięki przewidywalnym i stabilnym wpływom finansowym, wśród których kluczowe znaczenie miały przychody uzyskiwane z podatków płaconych przez elektrownię i duże przedsiębiorstwa ulokowane w jej pobliżu. 
Na zakończenie warto zwrócić uwagę na to, że wielkie inwestycje przemysłowe często sprzyjają generowaniu sytuacji konfliktowych. Ich przebieg i dynamika rozgrywają się na wielu płaszczyznach, a rozwiązania legislacyjne, w analizowanym przypadku argumentowane bezpieczeństwem energetycznym kraju, przynajmniej potencjalnie mogłyby doprowadzić do rozbieżności postaw pomiędzy interesariuszami a poziomem lokalnego, społecznego przyzwolenia. Wypowiedzi, informacje, konsultacje prowadzone (czasem niemal niedostrzegalnie dla mieszkańców gminy) przez zwolenników, jak również przeciwników inwestycji nie miały większego znaczenia. Korzyści z rozbudowy przeważały nad tymczasowymi uciążliwościami. Dostrzegli je przede wszystkim lokalni przedsiębiorcy oraz przedstawiciele władz gminy, a dowodów na to dostarczają przytoczone wyżej przykłady. Perspektywa zaistnienia konfliktu wydawała się odległa, bowiem zarówno mieszkańcom gminy, jak i inwestorowi zależało na współpracy. Jedna i druga strona czerpała $\mathrm{z}$ tego korzyści. Inwestor nie musiał borykać się z efektami protestów, mieszkańcy mogli liczyć na godziwy zarobek i wpływy pochodzące z przyszłych podatków na rzecz gminy.

Tymczasem ustabilizowana sieć powiązań pomiędzy różnymi typami instytucji na terenie gminy została mimo wszystko przerwana wtedy, gdy na szczeblu ponadlokalnym zapadły nagłe i nieprzewidziane decyzje o przyłączeniu dużej części gminy do miasta Opole. Motywowana koniecznością uzyskania nowych terenów inwestycyjnych decyzja prezydenta Opola zaakceptowana została przez rząd, a jej konsekwencją była utrata przez gminę Dobrzeń Wielki pięciu sołectw. Ich obszar to około $30 \%$ powierzchni gminy zamieszkiwanej przez porównywalny odsetek ludności. Na przyłączonym do miasta terytorium znalazły się elektrownia oraz wiele zakładów przemysłowych, które stanowiły dotąd o potencjale gospodarczym gminy. $Z$ punktu widzenia lokalnej ekonomii było to wydarzenie bez precedensu, bowiem zaburzało, a wręcz niszczyło wypracowywany przez wiele lat ład społeczno-ekonomiczny gminy. Powstało również zagrożenie pojawienia się zjawisk, które w wielopoziomowy i nagły sposób mogły wpłynąć na życie mieszkańców. Tak też się stało. Deficyt budżetowy pomniejszonej gminy sprawił, że bez zewnętrznych jednorazowych dotacji w latach 2017 i 2018 groziłoby jej bankructwo. Według przewidywań lokalnych władz bez radykalnych cięć finansowych i ograniczenia lub rezygnacji z zaplanowanych inwestycji, istnienie gminy jako samodzielnej jednostki samorządowej stanęło pod znakiem zapytania. Już w 2017 roku na przykład rozpoczęły się redukcje pracowników w gminnym ośrodku kultury oraz urzędzie gminy, nauczyciele zostali pozbawieni stosunkowo wysokich dodatków motywacyjnych do pensji, znacznie ograniczone bądź zlikwidowane zostały atrakcyjne dopłaty dla zakładów opiekuńczo-wychowawczych i stypendia dla uczniów, zmniejszono liczbę instruktorów sportowych czy też zrezygnowano $\mathrm{z}$ dotowania wymiany przestarzałych pieców grzewczych na nowoczesne systemy ogrzewania. Ponadto gmina pozbawiona została atrakcyj- 
nych terenów inwestycyjnych. Aktualność straciły też plany zagospodarowania przestrzennego.

Rozstrzygnięcia podjęte na wysokich szczeblach władzy i narzucone odgórnie bez jakichkolwiek konsultacji społecznych, zatem wymuszone i niespodziewane, doprowadziły do dramatycznej sytuacji. W rezultacie doskonale prosperująca i najbogatsza gmina wiejska na Opolszczyźnie została zdegradowana do gminy o peryferyjnym charakterze, stając przed problemami, których od wielu lat nie doświadczała. Konsekwencją takiego stanu rzeczy była i jest konieczność wypracowania nowych strategii ukierunkowanych na przetrwanie gminy w nowych warunkach. Jeśli nowe strategie okażą się z różnych powodów niemożliwe do zrealizowania, gminie grozi upadłość. Decyzja z początku 2016 roku o podziale gminy i przyłączeniu jej znacznego obszaru do miasta Opole została odczytana przez większość mieszkańców bardzo negatywnie i potraktowana jako niczym nieuzasadniona ingerencja w ich życie i osiągnięcia jako społeczności lokalnej. Skutkiem tego były długotrwałe protesty w obronie jedności gminy i jej obywateli, przestrzeni społecznej, która powinna pozostać nienaruszona jako jedna z podstawowych wartości. $Z$ tego powodu podjęto walkę o zatrzymanie procesu podziału gminy, nawet kosztem rezygnacji z ogromnych wpływów finansowych pochodzących z Elektrowni Opole. Dotychczas działania lokalnych i regionalnych liderów nie zostały uznane za istotne, ważniejsza okazała się polityka władz centralnych, nieuwzględniająca zmieniającej się dynamicznie rzeczywistości ekonomicznej gminy.

Jednak, jak wynika z badań prowadzonych w 2017 roku, zmiana granic gminy nie wpłynęła znacząco na zakres działań lokalnych przedsiębiorców, którzy wskazują jedynie na drobne niedogodności związane z koniecznością zmiany dokumentów, informacji na folderach reklamowych i stronach internetowych. Podkreślają oni natomiast możliwość pojawienia się zagrożeń wynikających z funkcjonowania tak zwanego otoczenia biznesu wtedy, gdy jego zapleczem dla wielu z nich stanie się nie bogata, otwarta na inicjatywy gmina, ale gmina biedna lub duże miasto ze skomplikowaną strukturą administracyjno-organizacyjną.

Istotne jest $\mathrm{w}$ tym przypadku zbliżające się zakończenie procesu rozbudowy elektrowni, a co za tym idzie - kurczenie się przedsięwzięć gospodarczych z procesem tym związanych. Pierwsze symptomy tej sytuacji są już widoczne w postaci ograniczonego popytu na towary i usługi. Dobrym przykładem ilustrującym to zjawisko są na przykład prośby kierowane do kierownictwa przyelektrownianego hotelu „Pod Kominem” o przekwaterowanie części gości do lokalnych kwater, gdyż ich właściciele nie są w stanie spłacać kredytów zaciągniętych w bankach, a przeznaczonych na powstanie i prowadzenie bazy noclegowej. Możliwy upadek wielu miejscowych małych firm wraz $\mathrm{z}$ diametralnie uszczuplonym budżetem gminnym stanowi przesłankę do stwierdzenia prawdopodobieństwa regresu gospodarczego gminy i pokazuje, jak krótka może być droga od szybkiego gospodarczego rozwoju do stagnacji. 
Badania prowadzone w gminie Dobrzeń Wielki wykazały, że wielka inwestycja przemysłowa sprzyja powstawaniu skomplikowanej sieci powiązań pomiędzy lokalną a ponadlokalną ekonomią. Co ciekawe, tam gdzie można by się spodziewać napięć i konfliktów, ich nie stwierdzono. Przeciwnie - relacje pomiędzy Elektrownią Opole oraz konsorcjum prowadzącym prace przy rozbudowie a władzami gminy i miejscowymi przedsiębiorcami sprzyjały nawiązaniu różnych form współpracy. Sytuacja konfliktowa zaistniała nieoczekiwanie. To nie ingerencja wielkiego przemysłu, ale ingerencja władz państwa w strukturę administracyjną gminy wywołała zjawiska konfliktowe, których efekty mogą stanowić niezwykle interesujący przedmiot badań w przyszłości.

\section{Bibliografia}

Buchowski M.

1995 Klasa i kultura w okresie transformacji: Antropologiczne studium przypadku społeczności lokalnej w Wielkopolsce, Poznań.

2018 Czyściec. Antropologia neoliberalnego postsocjalizmu, Poznań.

Cichocki P., Dudek K.J., Rakowski T. (red.)

2015 Oddolne tworzenie kultury. Perspektywa antropologiczna, Warszawa.

Kałuża R.

2000 Rola elektrowni „Opole” na rynku pracy, w: W. Lesiuk, R. Rauziński, T. Sołdra-Gwiżdż (red.), Między przeszłością a przyszłością. Elektrownia „Opole” jako czynnik zmiany społecznej, Opole, s. 59-64.

Kuligowski W., Stanisz A.

2017 Ruchome modernizacje. Między Autostrada Wolności a „starq dwójką”, Warszawa. Lesiuk W.

2000 Przeszłość $i$ współczesność okolic Dobrzenia Wielkiego w badaniach Państwowego Instytutu Naukowego - Instytutu Ślaskiego w Opolu, w: W. Lesiuk, R. Rauziński, T. Sołdra-Gwiżdż (red.), Między przeszłością a przyszłością. Elektrownia „Opole” jako czynnik zmiany społecznej, Opole, s. 7-12.

Rakowski T.

2009 Łowcy, zbieracze, praktycy niemocy. Etnografia człowieka zdegradowanego, Gdańsk.

Szaban D.

2017 Gra o węgiel. Socjologiczne uwarunkowania konfliktu wokót planów powstania kompleksu energetyczno-wydobywczego w województwie lubuskim, Warszawa. 